\title{
Contributions on Computer Music from the SBCM 2019
}

\section{Contribuições em Computação Musical do SBCM 2019}

\author{
Tiago Fernandes Tavares ${ }^{1 *}$, Flávio Luiz Schiavoni²
}

\begin{abstract}
The Brazilian Symposia on Computer Music are events that foster a rich environment for exciting interdisciplinary discussion. In its 17th edition, in 2019, the event was held in São João Del Rei, MG. This special issue presents 5 selected papers from the conference's technical program covering different research fields like sound synthesis, music information retrieval, sound systems, and digital musical instruments.

Keywords: Brazilian Symposia on Computer Music - Computer Music — Special Issue

Resumo: Os Simpósios Brasileiros de Computação Musical são eventos que promovem um rico ambiente para a discussão interdisciplinar. Em sua 17a edição, em 2019, o evento ocorreu em São João Del Rei, MG. Esta edição especial apresenta 5 artigos selecionados do programa científico, cobrindo diferentes áreas de pesquisa como síntese de som, recupertação de informações em música, sistemas sonoros, e instrumentos musicais digitais.

Palavras-Chave: Simpósios Brasileiros de Computação Musical - Computação Musical - Edição Especial

${ }^{1}$ Department of Computer Engineering and Industrial Automation / School of Electrical and Computer Engineering, University of Campinas, São Paulo - Brazil

${ }^{2}$ Department of Computer Science, Federal University of São João del-Rei, Minas Gerais - Brazil

*Corresponding author: tavares@dca.fee.unicamp.br and fls@ufsj.edu.br

DOI: http://dx.doi.org/10.22456/10.22456/2175-2745.116606 — Received: 21/01/2021 • Accepted: 21/01/2021

CC BY-NC-ND 4.0 - This work is licensed under a Creative Commons Attribution-NonCommercial-NoDerivatives 4.0 International License.
\end{abstract}

\section{Introduction}

The Brazilian Symposia on Computer Music (SBCM) started in 1994 as thriving and exciting venues for sharing ideas about recent developments in the fields of Computer Music, Sound and Music Computing, Music Information Retrieval, Computational Musicology, Multimedia Performance, and other themes related to art, science, and technology. SBCM is a biannual event organized by the Computer Music Interest Group $(\mathrm{CECM})^{1}$ of the Brazilian Computing Society $(\mathrm{SBC})^{2}$.

It's 17th edition took place in $2019^{3}$ at the Federal University of São João del-Rei, Brazil, from September 25th to September 27th. The conference program included keynote talks, oral presentations of music and technical papers, poster discussion sessions, discussion panels, workshops, and concerts. It provided plenty of opportunities for interaction and discussion, aiming to foster collaborations and novel ideas for the critical problems of our related fields.

The SBCM 2019 had also a call for Research group report, a topic to present actual research developed in institutions like Universities and / or Research centers focused on Computer

\footnotetext{
${ }^{1}$ More information about the CECM can be found on $\langle\mathrm{https}: / / \mathrm{www} . \mathrm{sbc}$. org.br/14-comissoes/385-computacao-musical $\rangle$.

${ }^{2}$ More information at $\langle$ https://www.sbc.org.br/ $\rangle$.

${ }^{3}$ The conference website is available on /http://compmus.ime.usp.br/ $\mathrm{sbcm} / 2019 /\rangle$.
}

Music subjects. This call was focused on projects, students involved, software developed, research focus and other subjects that can be interesting to the whole community.

The conference proceedings ${ }^{4}$ feature the contributions presented at SBCM 2019, including full technical papers, full music papers, posters, workshops, keynote talks, research group report, and art. They express the ongoing exchange taking place among the fields of music, computer science and engineering, among others, and their contributions to the advancement of scientific and artistic practices.

In the 2019 edition, the call for art, music and scientific contributions received 57 submissions in the scientific track. In total, 45 referees worked hard in a double-blind peerreview process. They contributed with almost 260 evaluations, which lead to the acceptance of 50 (87\%) of the submissions. We also had 7 research group reports including works from Espírito Santo [1], Minas Gerais [2, 3], Pernambuco [4], Rio Grande do Sul [5], and São Paulo [6, 7].

\footnotetext{
${ }^{4}$ Check our archive! This archive contains links to all previous editions of the event, giving access to the full digital content made available in each year, including the electronic proceedings: 〈http://compmus.ime.usp.br/sbcm/〉.
} 


\section{SBCM 2019 topics}

SBCM called for papers in many different topics, mostly following the previous editions of the Symposium. As shown in Table 1, there was particular interest in submitting articles on Computer Music and Creative Process (19 submissions), Music Information Retrieval (15 submissions), Music Analysis and Synthesis (13 submissions), and Real-Time Interactive Systems (13 submissions), which respectively indicate an alignment between SBCM and other conferences such as International Computer Music Conference (ICMC), International Society for Music Information Retrieval (ISMIR), Sound and Music Computing (SMC), and New Interfaces for Musical Expression (NIME).

Conversely, we can see that the least popular topics - both because of the number of submissions and the number of interested TPC members - were Audio Hardware Design, Distributed Music, Music Database Management, and Quality of Service for Audio. This might be an indication that these topics are being absorved by other conferences.

Interestingly, "Computer-Aided Music Education" has brought interest from many reviewers, but there were no articles accepted in this topic. Although the TPC interest shows it is a relevant topic, little research about it is being presented at SBCM.

\section{Selected papers for this special issue}

After the conference, the scientific committee selected five papers to be extended and published in this special issue of the Revista de Informática Teórica e Aplicada (RITA). The article selection focused on achieving a higher number of author groups, which meant selecting the better evaluated articles while restricting the number of articles from each group to one. In this way, the scientific committee aimed at showcasing the richness and diversity of scientific work in Brazilian computer music.

This special issue comprises five articles, which are extended versions of the ones published in the SBCM 2019 proceedings.

Low-Latency fo Estimation for the Finger Plucked Electric Bass Guitar Using the Absolute Difference Function[8] Extracting information from a digital audio signal is part of the research in a field called Music Information Retrieval, a common subject to SBCM conferences. This article shows how to exploit specific characteristics of the bass guitar note waveform to detect its pitch even before a fundamental frequency has formed in the string. This is specially relevant for low-latency applications such as controlling MIDI devices using audio[9].

Creating Digital Musical Instruments with libmosaic-sound and Mosaicode[10] Creating applications related to computer music is certainly an common activity in our conference program. There are several Software systems and Languages for Sound and Music to help researchers and newbies to create musical applications. This paper presents Libmosaic, a programming library written in C language that can help developing Digital Musical Instruments (DMI) within the Mosaicode visual programming environment. It facilitates creation so that music creation and DMI programming can be more intertwined[11].

A Model for Predicting Music Popularity on Streaming Platforms[12] Artificial Intelligence is a field strongly related to Computer music using Neural Networks, for instance, to analyze large musical data and predict some behavior. This article proposes to use a neural network to predict if a music track will become popular in streaming platforms. This type of system can be very useful for producers, as it can point out that some tracks are not yet fit for particular markets, or help selecting which track should be released as a single[13].

Challenges and Perspectives on Real-time Singing Voice Synthesis[14] Another interesting field to Computer music research is Sound Analysis and Synthesis. This review article discusses problems related to real-time voice synthesis. It focuses on the latest developments in this field, an can be an important starting point for other researchers starting in this topic[15].

Iracema: a Python library for audio content analysis[16] Mixing Software Systems Development and Music Information Retrieval fields, this paper presents Iracema, a Python library able to extract several pieces of information from monophonic audio. It simplifies the manipulation of time series and the segment analysis[17].

\section{Acknowledgements}

Authors would like to thank professor Márcio Dorn, all the Organizing Committee and participants of SBCM 2019, and all the Brazilian community on Computer Music. If you want to join us, please, subscribe our mailing list ${ }^{5}$.

\section{Author contributions}

Flávio Schiavoni and Tiago Tavares are the actual coordinators of the Computer Music Interest Group (CECM) and part of the SBCM 2019 Organizing Committee.

\section{References}

[1] COSTALONGA, L. et al. Nescom research report (2019). In: SCHIAVONI, F. et al. (Ed.). Proceedings of the 17th Brazilian Symposium on Computer Music. São João del-Rei - MG - Brazil: Sociedade Brasileira de Computação, 2019. p. 151-154.

\footnotetext{
${ }^{5}$ If you want to keep it on track, please, subscribe our mailing list: $\langle$ https: //grupos.ufrgs.br/mailman/listinfo/CompMus-1/ $\rangle$.
} 
Table 1. Number of papers and reviewers per topic.

\begin{tabular}{|c|c|c|c|c|c|c|}
\hline Topic & Accepted & Rejected & Total & $\begin{array}{l}\text { TPC Member } \\
\text { interested }\end{array}$ & $\begin{array}{l}\text { TPC Member } \\
\text { not interested }\end{array}$ & Difference \\
\hline Acoustics, Diffusion and Sonorization & 1 & 0 & 1 & 4 & 7 & -3 \\
\hline Artificial Intelligence, A-Life and Evolutionary Music Systems & 3 & 2 & 5 & 18 & 4 & 14 \\
\hline Audio Hardware Design & 0 & 1 & 1 & 3 & 13 & -10 \\
\hline Brain-Computer Interfaces and Physiological Signals & 1 & 0 & 1 & 8 & 9 & -1 \\
\hline Computer-Aided Music Education & 0 & 1 & 1 & 16 & 3 & 13 \\
\hline Computational Musicology & 5 & 1 & 6 & 12 & 5 & 7 \\
\hline Computer Music and Creative process & 17 & 2 & 19 & 19 & 0 & 19 \\
\hline Digital Sound Processing & 8 & 0 & 8 & 13 & 4 & 9 \\
\hline Digital Music Systems and Services & 2 & 1 & 3 & 3 & 8 & -5 \\
\hline Distributed Music & 0 & 0 & 0 & 2 & 8 & -6 \\
\hline Internet and Web Applications & 1 & 1 & 2 & 4 & 8 & -4 \\
\hline Movement and Gesture & 5 & 1 & 6 & 14 & 4 & 10 \\
\hline Multimedia Systems & 4 & 0 & 4 & 3 & 5 & -2 \\
\hline Music Analysis and Synthesis & 11 & 2 & 13 & 17 & 3 & 14 \\
\hline Music, Emotion and Communication & 3 & 0 & 3 & 9 & 5 & 4 \\
\hline Music Expressiveness & 6 & 2 & 8 & 12 & 4 & 8 \\
\hline Music Formats, Data Structures and Representation & 2 & 0 & 2 & 5 & 5 & 0 \\
\hline Music Information Retrieval & 14 & 1 & 15 & 11 & 4 & 7 \\
\hline Music Database Management & 0 & 0 & 0 & 1 & 12 & -11 \\
\hline Music Notation, Printing, and Optical Recognition & 1 & 0 & 1 & 9 & 7 & 2 \\
\hline Music Perception, Psychoacoustics and Cognition & 5 & 0 & 5 & 16 & 5 & 11 \\
\hline Music, Society and Technology & 11 & 1 & 12 & 11 & 4 & 7 \\
\hline Quality of Service for Audio & 0 & 0 & 0 & 0 & 15 & -15 \\
\hline Real-time Interactive Systems & 11 & 2 & 13 & 14 & 7 & 7 \\
\hline Sensors and Multimodal Signal Processing & 4 & 1 & 5 & 11 & 8 & 3 \\
\hline Software Systems and Languages for Sound and Music & 9 & 1 & 10 & 13 & 6 & 7 \\
\hline Sound Analysis and Synthesis & 3 & 0 & 3 & 17 & 4 & 13 \\
\hline
\end{tabular}

[2] LOUREIRO, M. et al. A retrospective of the research on musical expression conducted at cegeme. In: SCHIAVONI, F. et al. (Ed.). Proceedings of the 17th Brazilian Symposium on Computer Music. São João del-Rei - MG - Brazil: Sociedade Brasileira de Computação, 2019. p. 165-172.

[3] SCHIAVONI, F. et al. Alice: Arts lab in interfaces, computers, and everything else - research report (2019). In: SCHIAVONI, F. et al. (Ed.). Proceedings of the 17th Brazilian Symposium on Computer Music. São João del-Rei MG - Brazil: Sociedade Brasileira de Computação, 2019. p. 157-164.

[4] CALEGARIO, F.; CABRAL, G.; RAMALHO, G. Mustic: Research and innovation group on music, technology, interactivity and creativity. In: SCHIAVONI, F. et al. (Ed.). Proceedings of the 17th Brazilian Symposium on Computer Music. São João del-Rei - MG - Brazil: Sociedade Brasileira de Computação, 2019. p. 173-180.

[5] PIMENTA, M.; JOHANN, M.; SCHRAMM, R. Lcm-ufrgs research group report: What are we doing in computer music? In: SCHIAVONI, F. et al. (Ed.). Proceedings of the 17th Brazilian Symposium on Computer Music. São João del-Rei - MG - Brazil: Sociedade Brasileira de Computação, 2019. p. 181-188.
[6] TAVARES, T.; MASIERO, B. Computer music research at feec/unicamp: a snapshot of 2019. In: SCHIAVONI, F. et al. (Ed.). Proceedings of the 17th Brazilian Symposium on Computer Music. São João del-Rei - MG - Brazil: Sociedade Brasileira de Computação, 2019. p. 155-156.

[7] BARROS, P. V. I. de. Computer music research group ime/usp report for sbcm 2019. In: SCHIAVONI, F. et al. (Ed.). Proceedings of the 17th Brazilian Symposium on Computer Music. São João del-Rei - MG - Brazil: Sociedade Brasileira de Computação, 2019. p. 189-191.

[8] FONSECA, C.; TAVARES, T. Low-latency f0 estimation for the finger plucked electric bass guitar using the absolute difference function. Revista de Informática Teórica e Aplicada, v. 27, n. 4, p. 79-94, 2020. ISSN 21752745. Disponível em: 〈https: //seer.ufrgs.br/rita/article/view/RITA_VOL27_NR4_79 $\rangle$.

[9] FONSECA, C.; TAVARES, T. Low-latency f0 estimation for the finger plucked electric bass guitar using the absolute difference function. In: SCHIAVONI, F. et al. (Ed.).

Proceedings of the 17th Brazilian Symposium on Computer Music. São João del-Rei - MG - Brazil: Sociedade Brasileira de Computação, 2019. p. 125-130.

[10] GONÇALVES, L.; SCHIAVONI, F. Creating digital musical instruments with libmosaic-sound and mosaicode. 
Revista de Informática Teórica e Aplicada, v. 27, n. 4, p. 95-107, 2020. ISSN 21752745. Disponível em: 〈https: //seer.ufrgs.br/rita/article/view/RITA_VOL27_NR4_95〉.

[11] GONÇALVES, L.; SCHIAVONI, F. The development of libmosaic-sound: a library for sound design and an extension for the mosaicode programming environment. In: SCHIAVONI, F. et al. (Ed.). Proceedings of the 17th

Brazilian Symposium on Computer Music. São João del-Rei MG - Brazil: Sociedade Brasileira de Computação, 2019. p. 99-105.

[12] ARAUJO, C. S.; CRISTO, M. P. de; GIUSTI, R. A model for predicting music popularity on streaming platforms. Revista de Informática Teórica e Aplicada, v. 27, n. 4, p. 108-117, 2020. ISSN 21752745. Disponível em: 〈https: //seer.ufrgs.br/rita/article/view/RITA_VOL27_NR4_108〉.

[13] ARAUJO, C. S.; CRISTO, M.; GIUSTI, R. Predicting music popularity on streaming platforms. In: SCHIAVONI, F. et al. (Ed.). Proceedings of the 17th Brazilian Symposium on Computer Music. São João del-Rei - MG - Brazil: Sociedade Brasileira de Computação, 2019. p. 141-148.

[14] BRUM, L.; MORENO, E. Challenges and perspectives on real-time singing voice synthesis. Revista de Informática Teórica e Aplicada, v. 27, n. 4, p. 118-126, 2020. ISSN 21752745. Disponível em: 〈https: //seer.ufrgs.br/rita/article/view/RITA_VOL27_NR4_118 $\rangle$.

[15] BRUM, L.; MORENO, E. D. State of art of real-time singing voice synthesis. In: SCHIAVONI, F. et al. (Ed.).

Proceedings of the 17th Brazilian Symposium on Computer Music. São João del-Rei - MG - Brazil: Sociedade Brasileira de Computação, 2019. p. 50-57.

[16] MAGALHAES, T.; BARROS, F.; LOUREIRO, M. Iracema: a python library for audio content analysis.

Revista de Informática Teórica e Aplicada, v. 27, n. 4, p. 127-138, 2020. ISSN 21752745. Disponível em: 〈https: //seer.ufrgs.br/rita/article/view/RITA_VOL27_NR4_127 $\rangle$.

[17] MAGALHAES, T.; BARROS, F.; LOUREIRO, M. Iracema: a python library for audio content analysis. In: SCHIAVONI, F. et al. (Ed.). Proceedings of the 17th Brazilian Symposium on Computer Music. São João del-Rei MG - Brazil: Sociedade Brasileira de Computação, 2019. p. $22-27$. 